\title{
The interaction of silica nanoparticles with catalase and human mesenchymal stem cells: biophysical, theoretical and cellular studies
}

This article was published in the following Dove Press journal: International Journal of Nanomedicine

\author{
Mina Mousavi, '* Saman Hakimian, ',* \\ Twana Ahmed Mustafa, ${ }^{2}$ \\ Falah Mohammad Aziz, ${ }^{3}$ \\ Abbas Salihi, ${ }^{3,4}$ Mahsa Ale-Ebrahim, ${ }^{5, *}$ \\ Mirsasan Mirpour, ${ }^{6}$ Behnam Rasti, ${ }^{6}$ \\ Keivan Akhtari, $^{7}$ \\ Koorosh Shahpasand, ${ }^{8}$ \\ Osama K Abou-Zied, ${ }^{9}$ \\ Mojtaba Falahati ${ }^{10}$
}

'Department of Biochemistry and Biophysics, Faculty of Advanced Science and Technology,

Tehran Medical Sciences, Islamic Azad University,

Tehran, Iran; ${ }^{2}$ Department of Medical Laboratory

Technology, Health Technical College, Erbil

Polytechnic University, Erbil, Kurdistan Region,

Iraq; ${ }^{3}$ Department of Biology, College of Science,

Salahaddin University-Erbil, Kurdistan Region, Iraq;

${ }^{4}$ Department of Medical Analysis, Faculty of

Science, Tishk International University, Erbil, Iraq;

${ }^{5}$ Department of Physiology, Faculty of Advanced

Science and Technology, Tehran Medical Sciences,

Islamic Azad University, Tehran, Iran; ${ }^{6}$ Department

of Microbiology, Faculty of Basic Sciences, Lahijan

Branch, Islamic Azad University (IAU), Lahijan,

Guilan, Iran; ' Department of Physics, University of

Kurdistan, Sanandaj, Iran; ${ }^{8}$ Department of Stem

Cells and Developmental Biology, Cell Science

Research Center, Royan Institute for Stem Cell

Biology and Technology (RI-SCBT), Tehran, Iran

${ }^{9}$ Department of Chemistry, Faculty of Science,

Sultan Qaboos University, P.O. Box 36, Postal Code

123 Muscat, Oman; ${ }^{10}$ Department of

Nanotechnology, Faculty of Advanced Science and

Technology, Tehran Medical Sciences, Islamic Azad

University, Tehran, Iran

*These authors contributed equally to this work

Correspondence: Osama K Abou-Zied

Department of Chemistry, Faculty of Science,

Sultan Qaboos University, P.O. Box 36, 123

Muscat, Sultanate of Oman

Email abouzied@squ.edu.om

Mojtaba Falahati

Department of Nanotechnology, Faculty of

Advanced Science and Technology, Tehran

Medical Sciences, Islamic Azad University,

Tehran, Iran

Email Falahati@ibb.ut.ac.ir

\begin{abstract}
Aim: Nanoparticles (NPs) have been receiving potential interests in protein delivery and cell therapy. As a matter of fact, NPs may be used as great candidates in promoting cell therapy by catalase (CAT) delivery into high oxidative stress tissues. However, for using NPs like $\mathrm{SiO}_{2}$ as carriers, the interaction of NPs with proteins and mesenchymal stem cells (MSCs) should be explored in advance.
\end{abstract}

Methods: In the present study, the interaction of $\mathrm{SiO}_{2}$ NPs with CAT and human MSCs (hMSCs) was explored by various spectroscopic methods (fluorescence, circular dichroism (CD), UV-visible), molecular docking and dynamics studies, and cellular (MTT, cellular morphology, cellular uptake, lactate dehydrogenase, ROS, caspase-3, flow cytometry) assays. Results: Fluorescence study displayed that both dynamic and static quenching mechanisms and hydrophobic interactions are involved in the spontaneous interaction of $\mathrm{SiO}_{2} \mathrm{NPs}$ with CAT. CD spectra indicated that native structure of CAT remains stable after interaction with $\mathrm{SiO}_{2}$ NPs. UV-visible study also revealed that the kinetic parameters of CAT such as $\mathrm{Km}$, Vmax, Kcat, and enzyme efficiency were not changed after the addition of $\mathrm{SiO}_{2} \mathrm{NPs}$. Molecular docking and dynamics studies showed that $\mathrm{Si}$ and $\mathrm{SiO}_{2}$ clusters interact with hydrophobic residues of CAT and $\mathrm{SiO}_{2}$ cluster causes minor changes in the CAT structure at a total simulation time of $200 \mathrm{ps}$. Cellular assays depicted that $\mathrm{SiO}_{2} \mathrm{NPs}$ induce significant cell mortality, change in cellular morphology, cellular internalization, ROS elevation, and apoptosis in hMSCs at higher concentration than $100 \mu \mathrm{g} / \mathrm{mL}(170 \mu \mathrm{M})$.

Conclusion: The current results suggest that low concentrations of $\mathrm{SiO}_{2} \mathrm{NPs}$ induce no substantial change or mortality against CAT and hMSCs, and potentially useful carriers in CAT delivery to hMSC.

Keywords: silica nanoparticles, catalase, mesenchymal stem cells, interaction, spectroscopy, docking, molecular dynamics, cellular assays

\section{Introduction}

As nanotechnology is taking an increasing attention in fabrication of nanomaterial-based compounds for protein ${ }^{1}$ and cell delivery agents, ${ }^{2}$ revealing the impact of the physicochemical properties of nanoparticles (NPs) such as their chemical composition on the protein structures and cells viability has become critically necessary. ${ }^{3}$ Based on the unique properties of silica $\left(\mathrm{SiO}_{2}\right) \mathrm{NPs}$, they offer potential stem cell delivery ${ }^{4,5}$ and protein delivery ${ }^{6,7}$ applications. Hence, synthesis and development of novel $\mathrm{SiO}_{2}$-based multipotent carriers might be productive in the treatment of a wide range of diseases in vivo. However, before clinical applications of $\mathrm{SiO}_{2} \mathrm{NPs}$, their adverse effects should 
be examined against biological systems, such as proteins and cells in vitro. Actually, it may be indicated that NPs may induce some irreversible effects on the protein structure and cell viability. ${ }^{8}$ For example, it has been well documented that the interaction of iron NPs with BSA is spontaneous, causing some changes in the secondary structure of the protein. ${ }^{9}$ Data obtained from interaction of human hemoglobin with nanodiamond indicated that the hydrophobic interactions between nanodiamond and hemoglobin result in the significant secondary structural alteration of hemoglobin. ${ }^{10}$ Morever, it was specified that bare or functionalized titanium dioxide $\left(\mathrm{TiO}_{2}\right)$ NPs may induce different effects on the protein structure. ${ }^{11}$ It was also reported that composite NP like $\mathrm{TiO}_{2} /$ tungsten trioxide/graphene oxide can induce activity changes of catalase (CAT) and superoxide dismutase. ${ }^{12}$ Nonetheless, it was revealed that the electrostatic interaction between zinc oxide NPs and BSA results in the slight quaternary structural changes of the protein and the secondary structure of BSA retained its identity. ${ }^{13}$ Therefore, based on the type of NPs or the physicochemical characteristics of NPs, their kind of interaction and corresponding induced structural changes of the protein may provide different outcomes. Regarding cellular effects of NPs, some conflicting results have been also depicted. For example, the cytotoxicity effects of silver NPs, ${ }^{14}$ zinc oxide doped $\mathrm{TiO}_{2}$ nanocrystals ${ }^{15}$ and bismuth oxide NPs ${ }^{16}$ against human lung epithelial cells, human lung epithelial cells (A549) and human breast cancer (MCF-7) cells have been reported, respectively. But, it has been determined that some nanomaterials like iron NPs can serve as efficient and safe agents for internalization in the cells. ${ }^{17}$ In this regard, conflicting data have encouraged scientists to study the interaction of NPs with proteins and cells to explore the scenario behind the toxicity of NPs against biological systems. Meanwhile, to study the biological effects of $\mathrm{SiO}_{2} \mathrm{NPs}$ on protein structure, human erythrocyte CAT was chosen as the target macromolecule. CAT has a tetrameric structure with dominant $\alpha$-helix conformation and it protects the cells against hydrogen peroxide. ${ }^{18}$ As a consequence, any conformational changes of CAT result in its deactivation and elevation of oxidative stress accompanied by cell death. In this study, CAT interaction with $\mathrm{SiO}_{2}$ NPs was explored by spectroscopic and theoretical approaches.

Human mesenchymal stem cells (hMSCs) were also used to detect the cytotoxicity of $\mathrm{SiO}_{2}$ NPs against normal cells. MSCs-based therapies have shown potential applications in preclinical and clinical cases for treating a wide range of disorders. ${ }^{19,20}$ NPs can be used to increase MSCs therapeutic efficacy for several disorders. ${ }^{21,22}$ However, before the application of NPs as manipulating agents for MSCs differentiation, ${ }^{21}$ cytotoxicity of NPs like $\mathrm{SiO}_{2} \mathrm{NPs}$ as a function of viability and apoptosis should be explored to determine their biocompatibility. Also, it has been well documented that MSCs can be used as a potential cellular model for examining the cytotoxicity of engineered NPs. ${ }^{23}$ Consequently, hMSCs were also used to detect the cytotoxicity of $\mathrm{SiO}_{2}$ NPs.

\section{Materials and methods Material}

Alpha-minimum essential medium ( $\alpha$-MEM), FBS, L-glutamine, streptomycin and penicillin were purchased from Sigma-Aldrich Co. All other materials were of analytical grade.

\section{Methods}

\section{Fluorescence study}

CAT sample with a concentration of $2 \mu \mathrm{M}$ was titrated with different concentrations of $\mathrm{SiO}_{2}$ NPs $(1,5,10,15$ and 20 $\mu \mathrm{M})$ at 298,310 and $315 \mathrm{~K}$. Samples were then exited at 280 $\mathrm{nm}$ and emission was read at $340 \mathrm{~nm}$ using a Cary Eclipse VARIAN fluorescence spectrophotometer. The excitation and emission slits were fixed at 5 and $10 \mathrm{~nm}$, respectively. The phosphate buffer ( $\mathrm{pH} 7.4,20 \mathrm{mM}$ ) was used throughout the study. The fluorescence signal from the protein in the presence of NPs was subtracted from the fluorescence intensity of NPs and corrected for inner filter effect. In all experiments, CAT fluorescence intensity was measured in triplicate and the mean of the three data is reported.

\section{Circular dichroism (CD) study}

The CD signal of CAT with a concentration of $5 \mu \mathrm{M}$ in the absence and presence of $\mathrm{SiO}_{2} \operatorname{NPs}(5,10$, and $20 \mu \mathrm{M})$ was recorded by employing an AVIV 215 spectropolarimeter (Aviv Associates, Lakewood, NJ, USA). Ellipticity change $(\theta)$ of the protein in the wavelength range 190-260 nm was reported as the NPs concentration was increased from 5 to $20 \mu \mathrm{M}$. The experiment was performed at room temperature and the NPs and proteins were dissolved in

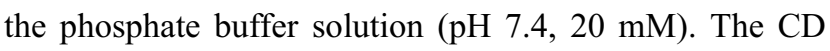
spectrum of CAT in the presence of NPs was subtracted from the spectra of NPs and buffer.

\section{CAT assay}

CAT activity was assayed based on the rate of $\mathrm{H}_{2} \mathrm{O}_{2}$ decomposition as determined by the reduction of absorbance at $240 \mathrm{~nm}$. The reaction mixture contained $970 \mu \mathrm{L}$ phosphate 
buffer (pH 7.4, $50 \mathrm{mM}), 10 \mu \mathrm{L}$ of 1-20 $\mathrm{mM} \mathrm{H}_{2} \mathrm{O}_{2}$ (3\%), 10 $\mu \mathrm{L}$ of $0.025 \mathrm{mg} / \mathrm{mL}$ CAT and $10 \mu \mathrm{L}$ of $10-50 \mu \mathrm{M}$ of $\mathrm{SiO}_{2}$ NPs. The experiment was done at room temperature and the data was reported as the average of three independent experiments.

\section{Molecular docking and dynamics}

$\left(\mathrm{SiO}_{2}\right)_{72}$ cluster was designed and used as a model of $\mathrm{SiO}_{2}$ NPs. This model was constructed by Cartesian coordinates of atoms obtained from Munde et $\mathrm{al}^{24}$ and Sabziparvar et $\mathrm{al}^{25}$ studies. In order to compare the effect of silica and silicon clusters, a $\mathrm{Si}_{20}$ cluster as a model of silicon NPs was designed using the Gaussian $98 \mathrm{~W}$ suite of program. ${ }^{25,26}$ The B3LYP functional with the $6-31 \mathrm{G}(\mathrm{d})$ basis set was used to study the interaction of clusters with CAT. HEX 6.3 software as a molecular docking program was used to calculate and display attainable docking modes of CAT and NP clusters. ${ }^{27} \mathrm{~A}$ spherical cluster of $\mathrm{SiO}_{2}$ NPs with a diameter of $30 \AA$ was constructed by repeating its unit cell for the simulation study. The molecular dynamic simulations were performed using Forcite code and universal force field. ${ }^{28}$

\section{Cell culture}

hMSCs derived from bone marrow were purchased from Royan Institute of Tehran, Iran. The extraction and purification of these cells were performed under Ethical Procedures approved by Ethical Committee of Royn Institute. The characterization of extracted cells based on surface marker expression was previously reported. ${ }^{29}$ Cells were cultured in $\alpha$-MEM medium containing FBS $(10 \%$, $\mathrm{v} / \mathrm{v})$, L-glutamine $(0.3 \mathrm{mg} / \mathrm{mL})$, streptomycin $(100 \mu \mathrm{g} / \mathrm{mL})$ and penicillin $(100 \mathrm{U} / \mathrm{mL})$ and kept at $37^{\circ} \mathrm{C}$ in a $5 \% \mathrm{CO}_{2}$. When hMSCs reached sub-confluence after five passages and after separation of non-adherent cells, varying concentrations of $\mathrm{SiO}_{2}$ NPs $(1,10,50,100$ and $200 \mu \mathrm{g} / \mathrm{mL})$ were added to the cell culture medium for $24 \mathrm{hrs}$.

\section{Cell viability analysis}

The viability percent of hMSCs in the presence of varying concentrations of $\mathrm{SiO}_{2}$ NPs $(1,10,50,100$ and $200 \mu \mathrm{g} /$ $\mathrm{mL}$ ) was analyzed using the MTT assay. Briefly, after treatment of cells for $24 \mathrm{hrs}, 10 \mu \mathrm{L}$ MTT with a concentration of $5 \mathrm{mg} / \mathrm{mL}$ was added to each well for $2 \mathrm{hrs}$. Then, the supernatant was gently removed and the formazone crystals were dissolved in $100 \mu \mathrm{L}$ DMSO. Finally, the absorbance intensity was measured at 570 $\mathrm{nm}$ using an ELISA reader (Expert 96, Asys Hitch, Ec
Austria). The cell viability percent was presented against the control samples.

\section{Cellular uptake of $\mathrm{SiO}_{2} \mathrm{NPs}$}

The uptake of $\mathrm{SiO}_{2}$ NPs was explored by flow cytometry (FACSCalibur; BD Biosciences, San Jose, CA, USA) based on our previous paper. ${ }^{30}$

\section{Cell morphology assay}

The cell morphology incubated with increasing concentrations of $\mathrm{SiO}_{2} \mathrm{NPs}(10,50,100$ and $200 \mu \mathrm{g} / \mathrm{mL})$ for $24 \mathrm{hrs}$ was observed employing invert microspore (Ziess, Germany).

\section{Lactate dehydrogenase (LDH) assay}

The cytotoxicity of $\mathrm{SiO}_{2}$ NPs against hMSCs was determined using a LDH assay kit (Colorimetric, ab102526) based on the manufacturer's protocol. Briefly, cells were cultured, treated with increasing concentrations of $\mathrm{SiO}_{2}$ NPs $(1,10,50,100$ and $200 \mu \mathrm{g} / \mathrm{mL})$ for $34 \mathrm{hrs}$, collected and incubated with reaction mixture. The output was read immediately at OD $450 \mathrm{~nm}$ to measure the LDH activity as a percentage of the control.

\section{Intracellular determination of ROS}

The generation of reactive oxygen radicals was analyzed using 2', $7^{\prime}$-dichlorofluorescein diacetate $\left[(\right.$ DCFDA $) / \mathrm{H}_{2}$ DCFDA - cellular ROS assay kit (ab113851)]. The DCF fluorescence intensity is extensively correlated with the generation of intracellular reactive oxygen species. Briefly, the cells were treated with different concentrations of $\mathrm{SiO}_{2}$ NPs $(1,10,50,100$ and $200 \mu \mathrm{g} / \mathrm{mL})$, collected in tubes, stained with DCFDA and incubated at $37^{\circ} \mathrm{C}$ for $30 \mathrm{~min}$. Afterward, the fluorescence intensity $\left(\lambda_{\mathrm{ex}}=495 \mathrm{~nm}, \lambda_{\mathrm{em}}=529\right.$ $\mathrm{nm}$ ) of solution was analyzed using FACScan cytometer (FACSCalibur; Becton-Dickinson, San Jose, CA, USA).

\section{Caspase- 3 activity assay}

The assay of caspase- 3 enzyme was carried out in cells treated with various concentrations of $\mathrm{SiO}_{2} \mathrm{NPs}(1,10,50$, 100 and $200 \mu \mathrm{g} / \mathrm{mL}$ ) using a commercially available kit (Caspase-3 assay kit [Colorimetric, ab39401]). Briefly, the control and the $\mathrm{SiO}_{2}$ NPs-treated cells were harvested after treatment for $24 \mathrm{hrs}$ and re-suspended in $50 \mu \mathrm{L}$ of chilled lysis buffer for 10 mins followed by centrifugation at $10,000 \mathrm{~g}$ for 5 mins. Protein concentration was then determined by Bradford assay and BSA was used as a standard. Supernatants were then incubated with caspase- 3 substrate (N-acetyl-DEVD-p-nitroaniline) at $37^{\circ} \mathrm{C}$ for $2 \mathrm{hrs}$ and absorbance intensity was analyzed at $405 \mathrm{~nm}$, using a microplate reader (Expert 96, Asys Hitch, Ec Austria). 


\section{Flow cytometry analysis}

Apoptosis quantification was done based on the manufacturer protocol of Annexin V-FITC Apoptosis Staining/ Detection Kit (ab14085). Briefly, after treatment with $200 \mu \mathrm{g} / \mathrm{mL}$ of $\mathrm{SiO}_{2}$ NPs for $24 \mathrm{hrs}$, hMSC $\left(1 \times 10^{6}\right)$ cells were collected by centrifugation, re-suspended, combined with $500 \mu \mathrm{L}$ of $1 \mathrm{X}$ Annexin $\mathrm{V}$ binding buffer, mixed with $5 \mu \mathrm{L}$ of Annexin V-FITC and $5 \mu \mathrm{L}$ propidium iodide (PI), and incubated at room temperature for 5 mins in the dark. Finally, the cells were analyzed by FACScan cytometer (FACSCalibur; Becton-Dickinson, San Jose, CA, USA).

\section{Statistical analysis}

Statistical analyses were performed using the SPSS software. Data were expressed as mean \pm SD of three independent experiments. One-way ANOVA and Student's $t$-test were done to determine statistical significance. Differences between groups were considered to be significant at $P<0.05$.

\section{Results}

\section{Synthesis and characterization of $\mathrm{SiO}_{2}$ NPs}

$\mathrm{SiO}_{2} \mathrm{NPs}$ with a size of about $20 \mathrm{~nm}$ were fabricated in our previous study by sol-gel method and were characterized by different approaches. ${ }^{31}$

\section{Quenching mechanism}

CAT sample was titrated by different doses of $\mathrm{SiO}_{2} \mathrm{NPs}$ at 298, 310 and $315 \mathrm{~K}$ and plots of fluorescence quenching are displayed in Figure 1. It can be deduced that quenching efficacy is varied by temperature. To quantify the impact of temperature and identify the quenching mechanism, the Stern-Volmer Equation (1) was plotted. ${ }^{32}$

$$
F_{o} / F=K_{S V}\left[\mathrm{SiO}_{2} \mathrm{NP}\right]+1=k_{q} \tau o\left[\mathrm{SiO}_{2} \mathrm{NP}\right]+1
$$

where $F_{o}, F, K_{S b}, k_{q}$ and $\tau o$ represent the fluorescence in the absence of ligand, fluorescence in the presence of ligand, Stern-Volmer constant, CAT quenching rate and lifetime of CAT fluorescence without ligand, respectively.

It was seen that the $K_{S V}$ values were $4.1 \pm 0.76 \times 10^{4}, 4.3$ $\pm 0.064 \times 10^{4}$ and $5.0 \pm 0.61 \times 10^{4} \mathrm{M}^{-1}$ at 298,310 and $315 \mathrm{~K}$, respectively (Figure 2, Table 1). Thus, as the $K_{S V}$ value increases by the elevation of temperature, a dynamic quenching system may be involved in the quenching mechanism of CAT by $\mathrm{SiO}_{2} \mathrm{NPs}^{32}$ Nevertheless, the $k q$ value was in the order of $10^{12}$, which is significantly greater than the dynamic quenching limit $\left(10^{10}\right)$, indicating a static quenching mechanism of CAT by $\mathrm{SiO}_{2}$ NPs (Table 1$) .{ }^{3}$ Hence, it may be suggested that both dynamic and static quenching mechanisms are involved in the fluorescence quenching of CAT by $\mathrm{SiO}_{2} \mathrm{NPs}^{32,33}$

\section{Binding parameters}

Figure 3 presents the variation of $\log (\mathrm{Fo}-\mathrm{F} / \mathrm{F})$ against $\log \left(\left[\mathrm{SiO}_{2} \mathrm{NPs}\right]\right)$ for CAT at 298,310 and $315 \mathrm{~K}$, calculated by using Equation (2). ${ }^{33}$

$$
\log [(F o-F) / F]=\log K_{b}+n \log \left[\mathrm{SiO}_{2} \mathrm{NP}\right]
$$

It yields a linear plot with binding constant $\left(\log K_{b}\right)$ of 2.28 $\pm 0.32,2.54 \pm 0.27$ and $2.98 \pm 0.41 \mathrm{M}^{-1}$ at 298,310 and $315 \mathrm{~K}$, respectively (Table 2). It was also revealed that there is almost a half binding site $(n)$ for $\mathrm{SiO}_{2}$ NPs in CAT. The half binding site suggests that two CAT molecules bind to one $\mathrm{SiO}_{2} \mathrm{NP}$.

\section{Thermodynamic parameters}

Figure 4 exhibits the variation of $\operatorname{Ln} K_{\mathrm{b}}$ against $1 / T$ at 298 , 310 and $315 \mathrm{~K}$, estimated by using van't Hoff Equation (3). ${ }^{34}$

$$
\operatorname{Ln} K_{b}=-(\Delta H / R T)+(\Delta S / R)
$$

It gives a slope which demonstrates the enthalpy change $(\Delta H)$ with a value of $69.67 \mathrm{~kJ} / \mathrm{mol}$ (Table 3 ). The entropy change $(T \Delta S)$ was estimated from the intercept to be 81.62 $\pm 9.11,84.90 \pm 10.28$ and $86.27 \pm 13.35 \mathrm{~kJ} / \mathrm{mol}$ at 298,310 and $315 \mathrm{~K}$, respectively. The positive signs of $\Delta H$ and $\Delta S$ demonstrate that hydrophobic forces are the main contributing interactions in the formation of the $\mathrm{SiO}_{2} \mathrm{NP} / \mathrm{CAT}$ complex. $^{35}$

Gibbs-Helmholtz Equation (4) was used to calculate the Gibbs free energy $(\Delta \mathrm{G}){ }^{35}$

$$
\Delta \mathrm{G}=\Delta \mathrm{H}--\mathrm{T} \Delta \mathrm{S}
$$

The $\Delta \mathrm{G}$ values were shown to be $-11.95 \pm 1.81,-15.23$ \pm 2.29 and $-16.60 \pm 2.41 \mathrm{~kJ} / \mathrm{mol}$ (Table 3) at 298,310 and $315 \mathrm{~K}$, respectively. The negative sign of $\Delta \mathrm{G}$ points to a spontaneous interaction between $\mathrm{SiO}_{2} \mathrm{NPs}$ and CAT.

\section{CD study}

$\mathrm{CD}$ is a potential technique usually employed for the detection of changes in secondary and tertiary conformation of protein. ${ }^{35,36}$ Backbone configuration of the protein is explored by the far-UV CD ellipticity changes within the range of 190-260 $\mathrm{nm}$. In this range of wavelength, the secondary structure of the protein represents a characteristic magnitudewhich can be denatured or 

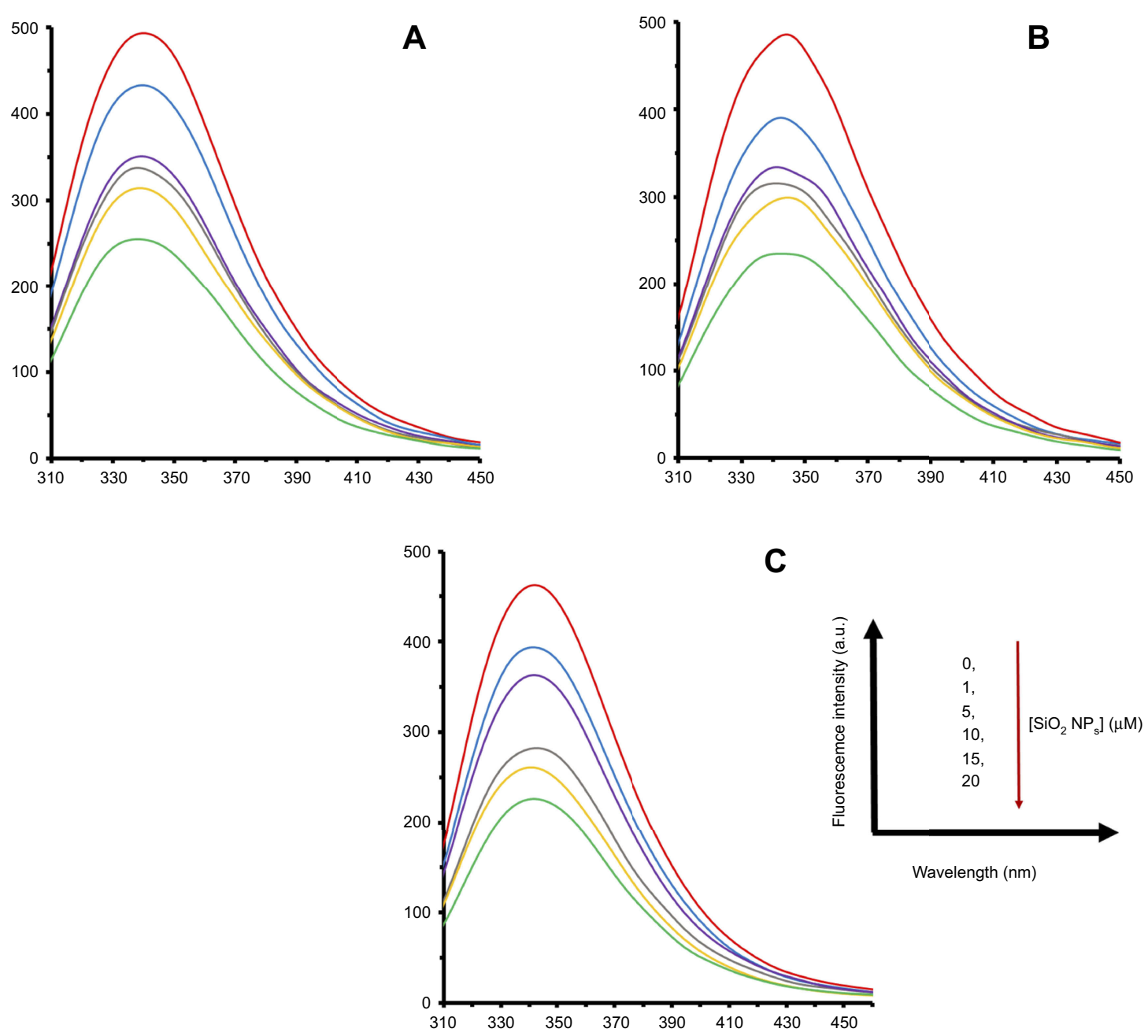

Figure I Fluorescence quenching of CAT in the presence of different concentrations of $\mathrm{SiO}_{2} \mathrm{NPs}: 0$ (red), I (blue), 5 (purple), 10 (grey), 15 (yellow) and $20 \mu \mathrm{M}$ (green) at 298 (A), 310 (B) and $315 \mathrm{~K}(\mathbf{C})$.

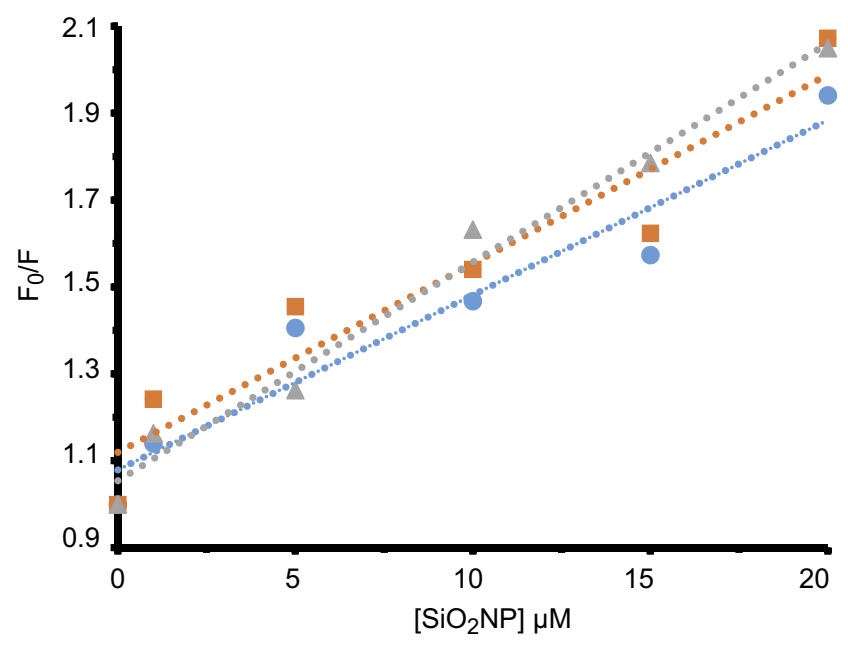

Figure 2 Stern-Volmer plots of CAT in the presence of different concentrations of $\mathrm{SiO}_{2} \mathrm{NPs}$ at 298 (blue), 310 (orange) and $315 \mathrm{~K}$ (grey).

destabilized by triggering the structural alterations during the binding of NPs to the protein. ${ }^{35}$ In order to explore the change in the secondary structure of CAT in the presence of varying concentrations of $\mathrm{SiO}_{2} \mathrm{NPs}$ (5, 10 and $20 \mu \mathrm{m})$, far-UV CD spectra were measured (Figure 5). The CD spectrum of CAT demonstrates two characteristic negative peaks at 208 and $222 \mathrm{~nm}$, indicating the alpha-helical configuration of CAT. Moreover, the CD spectra of CAT in the presence of varying concentrations of $\mathrm{SiO}_{2}$ NPs illustrate similar patterns, revealing the predominance of the $\alpha$-helical structure even in the presence of high dose of $\mathrm{SiO}_{2}$ NPs. The $\alpha$ helix content was not altered almost in the presence of $\mathrm{SiO}_{2}$ NPs, which depicts that the interaction between CAT and $\mathrm{SiO}_{2}$ NPs does not result in any significant change in the secondary structure of CAT. As deduced from Figure 5, the minimum positions and the ellipticity values of the $C D$ spectra are not changed even after enhancing the molar ratio of NP, evincing that the native structure of CAT remains stable after the interaction. ${ }^{35}$ 
Table I The $K_{s v}$ and $k q$ values for the $\mathrm{SiO}_{2}$ NPs/CAT complex at three different temperatures

\begin{tabular}{|l|l|l|l|}
\hline $\mathbf{T}$ & $\boldsymbol{K}_{\mathbf{s v}}\left(\mathbf{M}^{-1}\right)$ & $\mathbf{k q}\left(\mathbf{M}^{-\mathbf{1}} \mathbf{s}^{-1}\right)$ & $\mathbf{R}^{\mathbf{2}}$ \\
\hline 298 & $(4.1 \pm 0.76) \times 10^{4}$ & $(4.1 \pm 0.76) \times 10^{12}$ & 0.92 \\
310 & $(4.3 \pm 0.64) \times 10^{4}$ & $(4.3 \pm 0.64) \times 10^{12}$ & 0.91 \\
315 & $(5.0 \pm 0.61) \times 10^{4}$ & $(5.0 \pm 0.61) \times 10^{12}$ & 0.95 \\
\hline
\end{tabular}

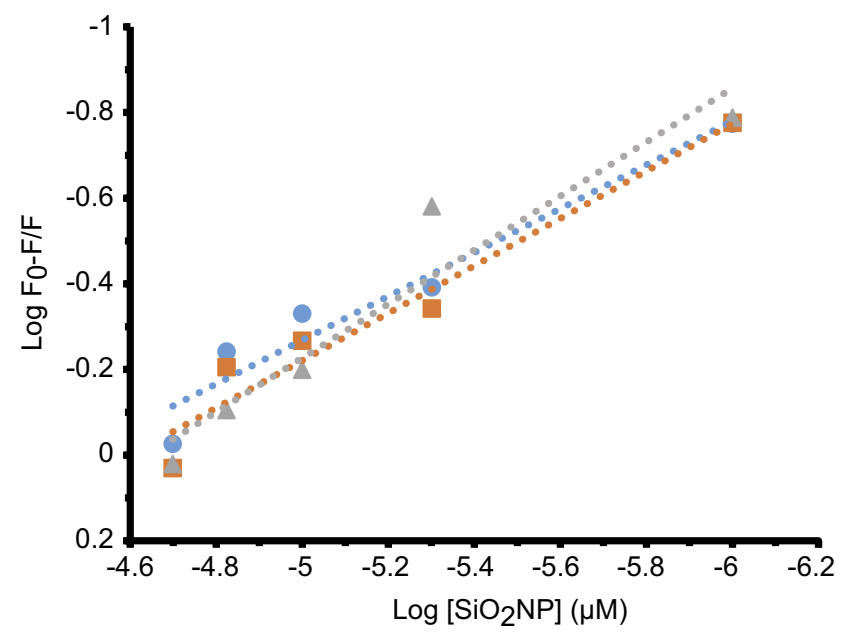

Figure 3 Modified Hill plot of CAT in the presence of different concentrations of $\mathrm{SiO}_{2} \mathrm{NPs}$ at 298 (blue), 310 (orange) and $315 \mathrm{~K}$ (grey).

Table 2 The $n$ and $\log K_{b}$ values for the $\mathrm{SiO}_{2}$ NPs/CAT complex at different temperatures

\begin{tabular}{|l|l|l|l|}
\hline $\mathbf{T}$ & $\mathbf{n}$ & $\log \boldsymbol{K}_{\mathbf{b}}\left(\mathbf{M}^{-1}\right)$ & $\mathbf{R}^{\mathbf{2}}$ \\
\hline 298 & $0.51 \pm 0.07$ & $2.28 \pm 0.32$ & 0.95 \\
310 & $0.55 \pm 0.08$ & $2.54 \pm 0.27$ & 0.95 \\
315 & $0.63 \pm 0.08$ & $2.92 \pm 0.41$ & 0.92 \\
\hline
\end{tabular}

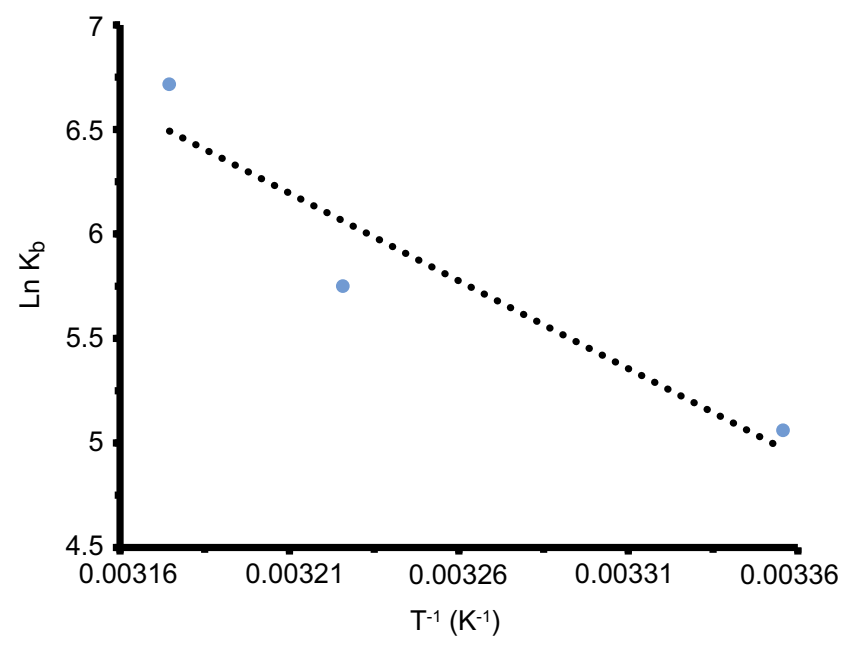

Figure 4 van't Hoff plot of CAT in the presence of $\mathrm{SiO}_{2} \mathrm{NPs}$ at 298,310 and $315 \mathrm{~K}$.

\section{Activity assay}

The influence of varying the concentration of $\mathrm{SiO}_{2} \mathrm{NPs}$ $(10-50 \mu \mathrm{M})$ on the CAT activity was explored. Table 4 summarizes the values of $\mathrm{Km}$, Vmax, Kcat and the efficiency of CAT in the presence of different concentrations of $\mathrm{SiO}_{2}$ NPs. It can be observed that $\mathrm{SiO}_{2} \mathrm{NPs}$ have not induced any significant effect on the CAT activity even at high concentrations. By increasing the concentration of $\mathrm{SiO}_{2} \mathrm{NPs}$, the kinetic parameters and efficiency of CAT were almost consistent. In fact, the efficacy of the enzyme was $7.1 \times 10^{7}$ and $6.5 \times 10^{7} \mathrm{~min}^{-1} \mathrm{mM}^{-1}$ in the absence and presence of $50 \mu \mathrm{M}$ $\mathrm{SiO}_{2} \mathrm{NPs}$, respectively. This data manifests that the CAT efficiency dropped to only $8.5 \%$ relative to the native enzyme when the $\mathrm{SiO}_{2}$ NPs concentration increased to 50 $\mu \mathrm{M}$, indicating that $\mathrm{SiO}_{2} \mathrm{NPs}$ tend to keep the CAT protein in its native state with no significant denaturation.

\section{Molecular docking}

At this stage, understanding the exact binding site of CAT is of crucial importance in order to understand the proteinNPs interaction. Administered or injected NPs may induce an affinity for the binding to the protein, formation of protein corona and results in the reduction of free fraction of the NPs. This binding affinity may play a pivotal role in the potential clinical consequence of NPs.

Molecular docking methods can predict the interaction between the protein and the NPs which have low or no similarity with real ligands. Accordingly, docking study can be used as a potential tool to define the binding affinity and the binding site of the protein that hosts the NPs. In the current study, the X-ray crystallographic structure of CAT was obtained from the protein data bank (1DGF) and molecular docking was carried out with NPs cluster as a ligand. The docked residues were visualized by using CHIMERA (www.cgl.ucsf.edu/chimera) and PyMOL (http://pymol.sour ceforge.net/) graphical tools. The docked $\left(\mathrm{SiO}_{2}\right)_{72} / \mathrm{CAT}$ and $\mathrm{Si}_{20} / \mathrm{CAT}$ systems are exhibited in Figure 6. The interacting residues of CAT with $\left(\mathrm{SiO}_{2}\right)_{72}$ and $\mathrm{Si}_{20}$ clusters with a cutoff distance of $4 \AA$ are shown in Figures 7 and 8, respectively. The nearest interacting residues for $\left(\mathrm{SiO}_{2}\right)_{72} / \mathrm{CAT}$ are Met394.B, Met-394.A, Pro-374.A, Tyr-379.A, Gln-395.B, Asp396.B, Gly-400.B, Gly-399.B, Gln-395.B and Val-323.A. For $\mathrm{Si}_{20} / \mathrm{CAT}$, the residues are Tyr-379.C, Pro-378.C, Cys377.C, Ala-381.C, Arg-382.C, Val-383.C, Gln-395.C and Asp-396.C. This data suggests that hydrophobic residues are dominant amino acids in the binding pocket of CAT during the interaction with the NPs cluster. The calculated 
Table 3 The thermodynamic parameters of $\mathrm{SiO}_{2}$ NPs/CAT complex at three different temperatures

\begin{tabular}{|l|l|l|l|}
\hline $\mathbf{T}$ & $\Delta \boldsymbol{H} \mathbf{( k J / m o l )}$ & $\boldsymbol{T} \Delta \boldsymbol{S}(\mathbf{k J} / \mathbf{m o l})$ & $\Delta \boldsymbol{G}(\mathbf{k J} / \mathbf{m o l})$ \\
\hline 298 & $69.67 \pm 8.34$ & $81.62 \pm 9.11$ & $-11.95 \pm 1.81$ \\
310 & $69.67 \pm 8.34$ & $84.90 \pm 10.28$ & $-15.23 \pm 2.29$ \\
315 & $69.67 \pm 8.34$ & $86.27 \pm 13.35$ & $-16.60 \pm 2.41$ \\
\hline
\end{tabular}

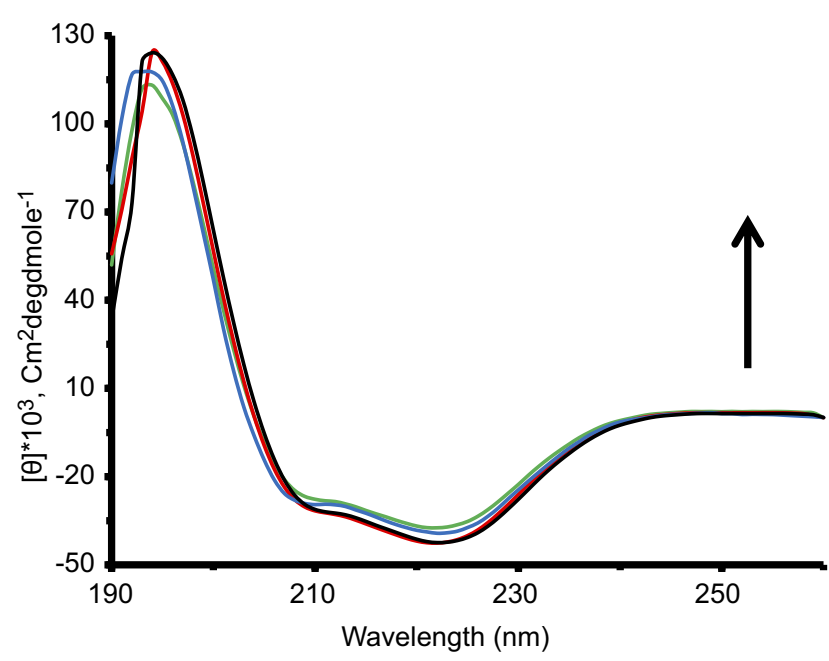

Figure $5 \mathrm{CD}$ spectra of CAT in the presence of different concentrations of $\mathrm{SiO}_{2}$ NPs: 0 (black), 5 (red), 10 (blue) and $20 \mu \mathrm{M}$ (green), at room temperature.

Table 4 The kinetic parameters of CAT in the presence of varying concentrations of $\mathrm{SiO}_{2} \mathrm{NPs}$

\begin{tabular}{|l|l|l|l|l|}
\hline $\begin{array}{l}{\left[\mathrm{SiO}_{2}\right.} \\
\mathrm{NP}] \\
(\mu \mathrm{M})\end{array}$ & $\begin{array}{l}\mathrm{Km} \\
(\mathrm{mM})\end{array}$ & $\begin{array}{l}\text { Vmax } \\
(\mathrm{mM} / \mathrm{min})\end{array}$ & $\begin{array}{l}\text { Kcat } \\
\left(\mathrm{min}^{-1}\right)\end{array}$ & $\begin{array}{l}\text { Efficiency } \\
\left(\mathrm{min}^{-1} \mathbf{m M}^{-1}\right)\end{array}$ \\
\hline 0 & $3.9 \pm 0.21$ & $2.8 \pm 0.11 \times 10^{-1}$ & $2.8 \times 10^{8}$ & $7.1 \times 10^{7}$ \\
10 & $3.9 \pm 0.19$ & $2.8 \pm 0.25 \times 10^{-1}$ & $2.8 \times 10^{8}$ & $7.1 \times 10^{7}$ \\
20 & $3.9 \pm 0.33$ & $2.7 \pm 0.17 \times 10^{-1}$ & $2.7 \times 10^{8}$ & $6.9 \times 10^{7}$ \\
50 & $4.0 \pm 0.39$ & $2.6 \pm 0.28 \times 10^{-1}$ & $2.6 \times 10^{8}$ & $6.5 \times 10^{7}$ \\
\hline
\end{tabular}

binding energies were found to be -519.95 and -248.30 E-value for $\left(\mathrm{SiO}_{2}\right)_{72}$ and $\mathrm{Si}_{20}$ clusters, respectively. As a result, it can be suggested that CAT displays a higher affinity toward $\left(\mathrm{SiO}_{2}\right)_{72}$ cluster than $\mathrm{Si}_{20}$ cluster.

\section{Molecular dynamics simulation}

Molecular dynamics study can potentially complement the experimental data for the protein/NPs systems. The models of NPs and protein were covered by 500 water molecules and the annealing process was used to set the equilibrium temperatures at $298 \mathrm{~K}$. The constant-energy, constant-volume ensemble with a time step of $1 \mathrm{fs}$, and a total simulation time of 200 ps were fixed in the simulations. Figure 9 delineates the complex in the beginning of the simulation and after 200 ps. As can be seen, the $\mathrm{SiO}_{2}$ cluster causes partial unfolding of the CAT structure in the binding site over time. In fact, the $\alpha$-helical structure of the protein remains almost intact after the interaction with $\mathrm{SiO}_{2} \mathrm{NPs}$. These results are in good agreement with $\mathrm{CD}$ spectroscopic results.

\section{MTT assay}

hMSCs cells were exposed to increasing concentrations of $\mathrm{SiO}_{2}$ NPs $(1,10,50,100$ and $200 \mu \mathrm{g} / \mathrm{mL})$ as detected by MTT assays (Figure 10). MTT data indicated a negligible cytotoxicity of $\mathrm{SiO}_{2}$ NPs against hMSCs up to $100 \mu \mathrm{g} / \mathrm{mL}$. However, increasing the concentration of $\mathrm{SiO}_{2} \mathrm{NPs}$ to 200 $\mu \mathrm{g} / \mathrm{mL}$ causes a significant reduction (63.94 \pm 4.72$)$ in the percent of viable cells after $24 \mathrm{hrs}$ compared to the control sample $\left({ }^{*} P<0.05\right)$ (Figure 10). The MTT assay demonstrates a dose-dependent cytotoxicity from which reliable data about the percentage of viable cells could be determined.

\section{Cellular internalization of $\mathrm{SiO}_{2} \mathrm{NPs}$}

The cytoplasmic internalization of $\mathrm{SiO}_{2}$ NPs by hMSCS was evaluated by flow cytometry analysis. A significant reduction in the fluorescent intensity of forward scatter (FSC) versus side scatter (SSC) subset (Figure 11A and B) was detected after hMSCs cells were incubated with $200 \mu \mathrm{g} / \mathrm{mL}$ of $\mathrm{SiO}_{2}$ NPs for $24 \mathrm{hrs}$. This is well established to be due to light reflection that derived from cellular NP internalization. ${ }^{36}$ Indeed, the fold enhancement in SSC of hMSCs and fold reduction in FSC of hMSCs exposed to $\mathrm{SiO}_{2} \mathrm{NPs}$ for $24 \mathrm{hrs}$ reveal the cellular internalization of NPs.

\section{Morphology of cells}

We also studied the morphological changes of hMSCs induced by different concentrations of $\mathrm{SiO}_{2}(0$ [Figure 12A], 10 [Figure 12B], 50 [Figure 12C], 100 [Figure 12D] and 200 $\mu \mathrm{g} / \mathrm{mL}$ [Figure 12E]). It was shown that morphological changes activated by increasing concentrations of $\mathrm{SiO}_{2} \mathrm{NP}$ $(1-100 \mu \mathrm{g} / \mathrm{ml}$ ) were not obvious in hMSCs (Figure 12A-D). However, hMSCs have experienced a shrinkage in cytoplasm and roundness of the cells following exposure to $200 \mu \mathrm{g} / \mathrm{mL}$ of $\mathrm{SiO}_{2} \mathrm{NP}$ (Figure 12E). This data suggests the occurrence of hMSCs morphological changes after exposure to high concentration of $\mathrm{SiO}_{2} \mathrm{NPs}$.

\section{LDH assay}

After 24 hrs incubation of hMSCs with $\mathrm{SiO}_{2} \mathrm{NPs}$, LDH assay demonstrated a very low level of toxicity for all 


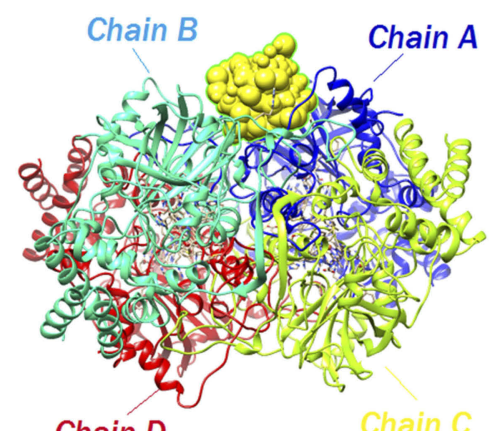

A

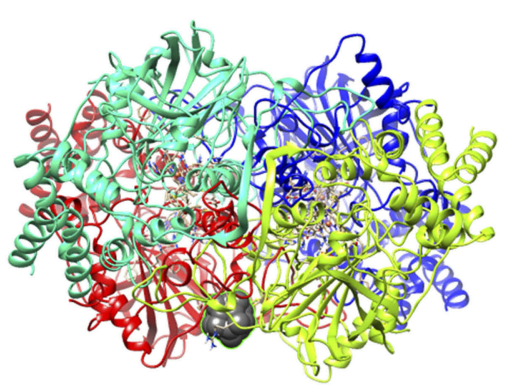

B

Figure 6 The docked $\left(\mathrm{SiO}_{2}\right)_{72} \mathrm{CAT}(\mathbf{A})$ and $\mathrm{Si}_{20} / \mathrm{CAT}(\mathbf{B})$ systems.
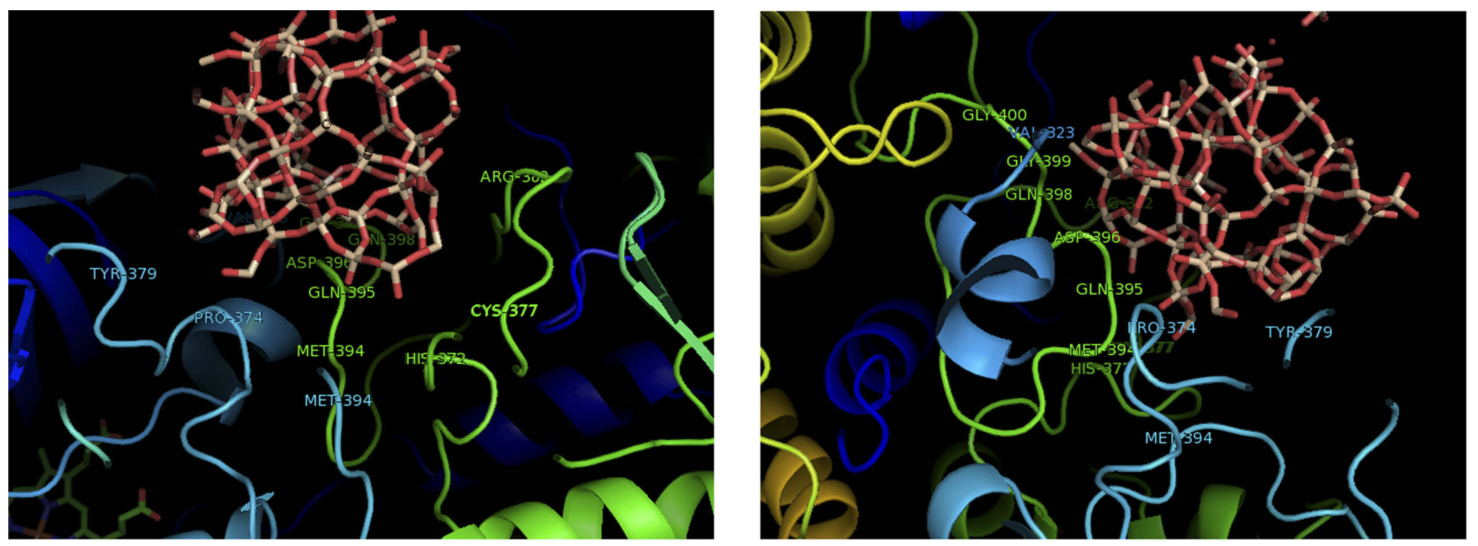

Figure 7 The interacting residues of CAT with $\left(\mathrm{SiO}_{2}\right)_{72}$ cluster from two different view angles.
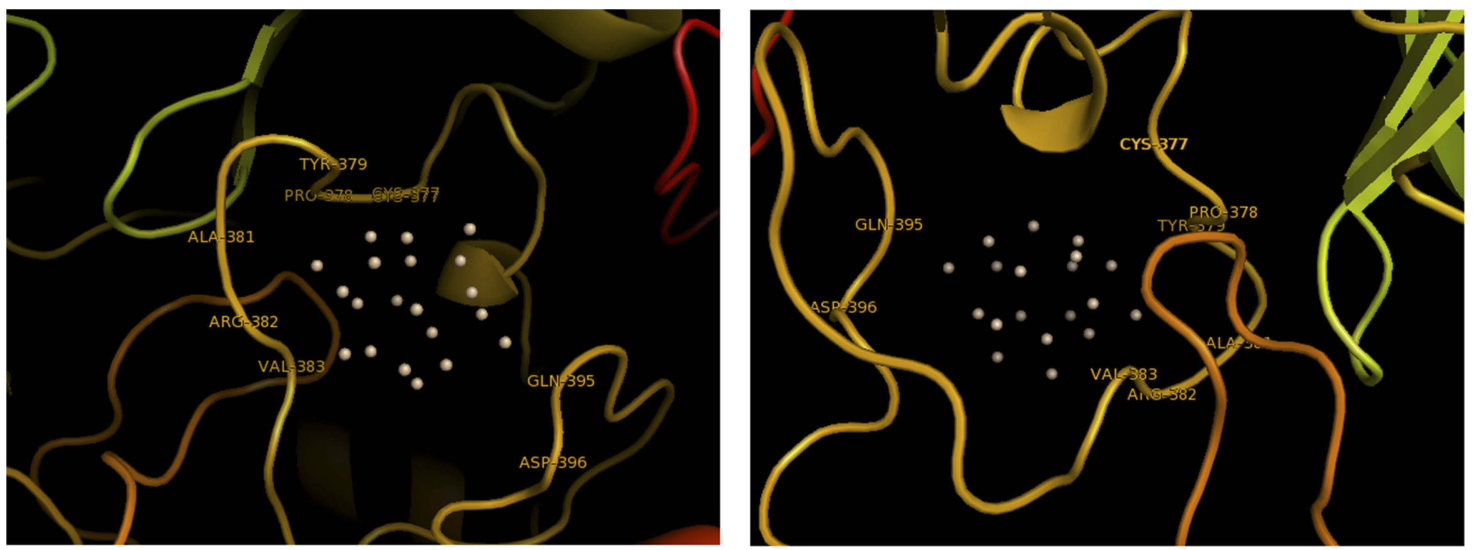

Figure 8 The interacting residues of CAT with $\mathrm{Si}_{20}$ cluster from two different view angles.

$\mathrm{SiO}_{2}$ NPs concentrations with membrane damage similar to the control samples (Figure 13). Indeed, LDH assay did not indicate a dose-dependent manner. The discrepancy between the MTT and the LDH assay data raised the probability that $\mathrm{SiO}_{2}$ NPs-induced cytotoxicity may occur through apoptosis rather than necrosis.

\section{Production of ROS}

hMSCs cells exposed to different concentrations of $\mathrm{SiO}_{2} \mathrm{NPs}$ $(1,10,50,100$ and $200 \mu \mathrm{g} / \mathrm{mL})$ for $24 \mathrm{hrs}$ also revealed a significant increase in the production of ROS only at high concentrations (100 and $200 \mu \mathrm{g} / \mathrm{mL}$ ), compared to the controls 

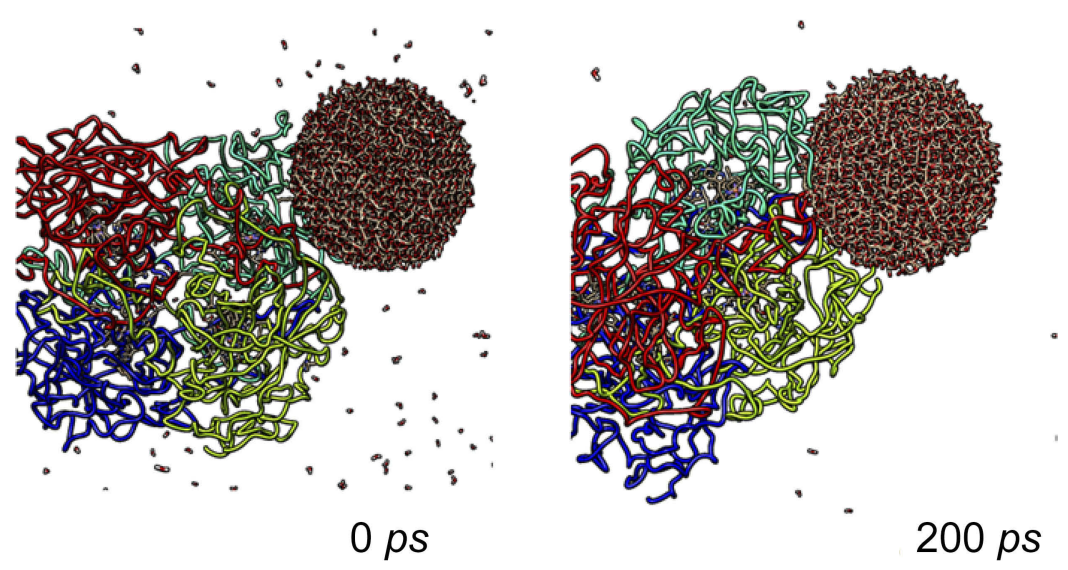

Figure $9 \mathrm{SiO}_{2}$ cluster/CAT complex in the beginning and after 200 ps simulation.

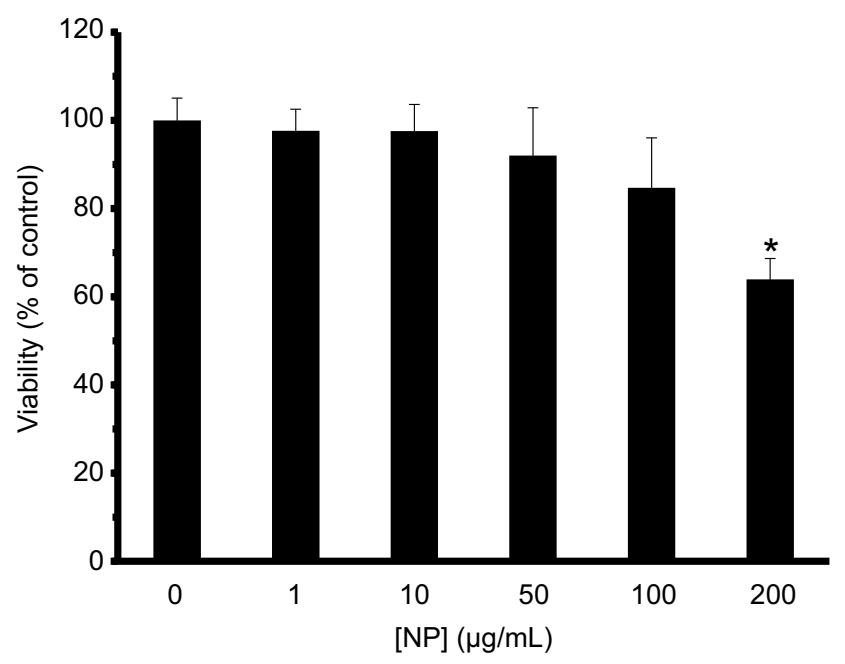

Figure $10 \mathrm{SiO}_{2} \mathrm{NPs}$ (up to $200 \mu \mathrm{g} / \mathrm{mL}$ ) decrease the viability of hMSCs. The cells were incubated with varying concentrations of $\mathrm{SiO}_{2} \mathrm{NPs}$ for $24 \mathrm{hrs}$ before MTT assay was carried out. $* P<0.05$ compared to the control group.

\section{A}

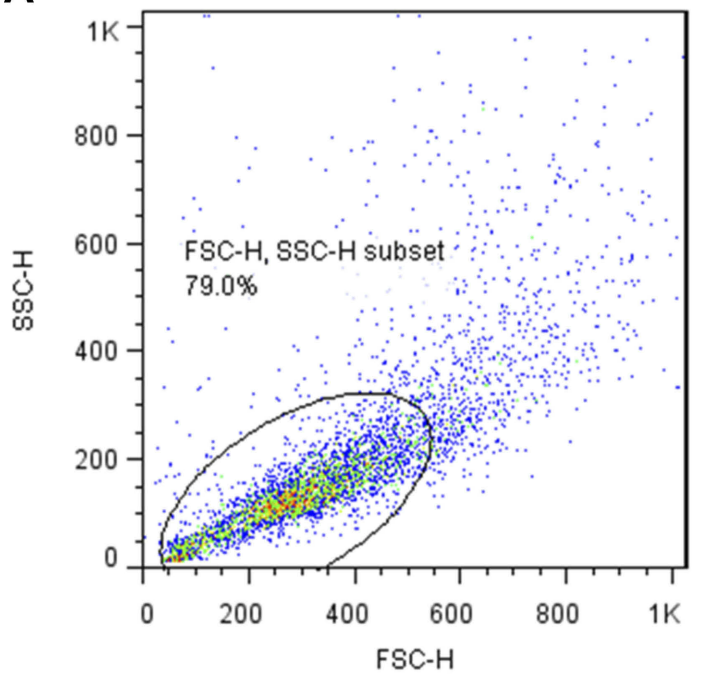

$\left({ }^{*} P<0.05\right)$ (Figure 14). We observed that different concentrations of $\mathrm{SiO}_{2}$ NPs $(1,10,50,100$ and $200 \mu \mathrm{g} / \mathrm{mL})$ produced $116.33 \pm 17.07, \quad 125.01 \pm 8.42, \quad 136.66 \pm 24.05, \quad 161.33 \pm 18.66$ $(* P<0.05), 185.11 \pm 9.90(* P<0.05)$, respectively. While for the negative control group, the level of ROS was determined to be $114.66 \pm 6.54$. On that account, the largest effect was observed for 100 and $200 \mu \mathrm{g} / \mathrm{mL}$ of $\mathrm{SiO}_{2}$ NPs as shown in Figure 14.

\section{Caspase- 3 assay}

Apoptotic stimuli including NPs result in apoptosis induction which is executed by the activation of caspases. Caspase- 3 activation was assessed by colorimetric assay after $24 \mathrm{hrs}$, by measuring the absorbance change at 405 nm. Figure 15 displays the results, where $\mathrm{SiO}_{2} \mathrm{NPs}$-induced activation of caspase- 3 as an effector enzyme can only be

B

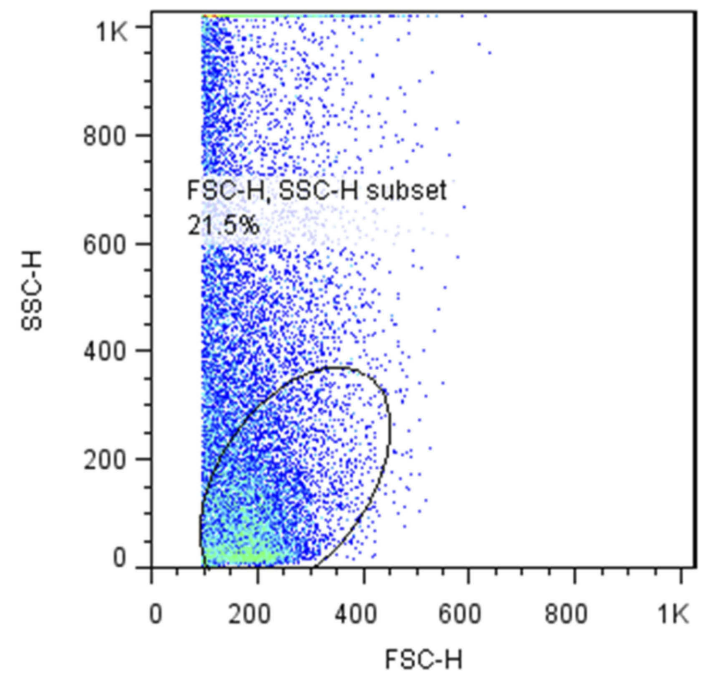

Figure I I Cellular internalization of $\mathrm{SiO}_{2} \mathrm{NPs}$ into the hMSCs. (A) Control cells and (B) treated cells with $\mathrm{SiO}_{2} \mathrm{NPs}(200 \mu \mathrm{g} / \mathrm{mL})$. 

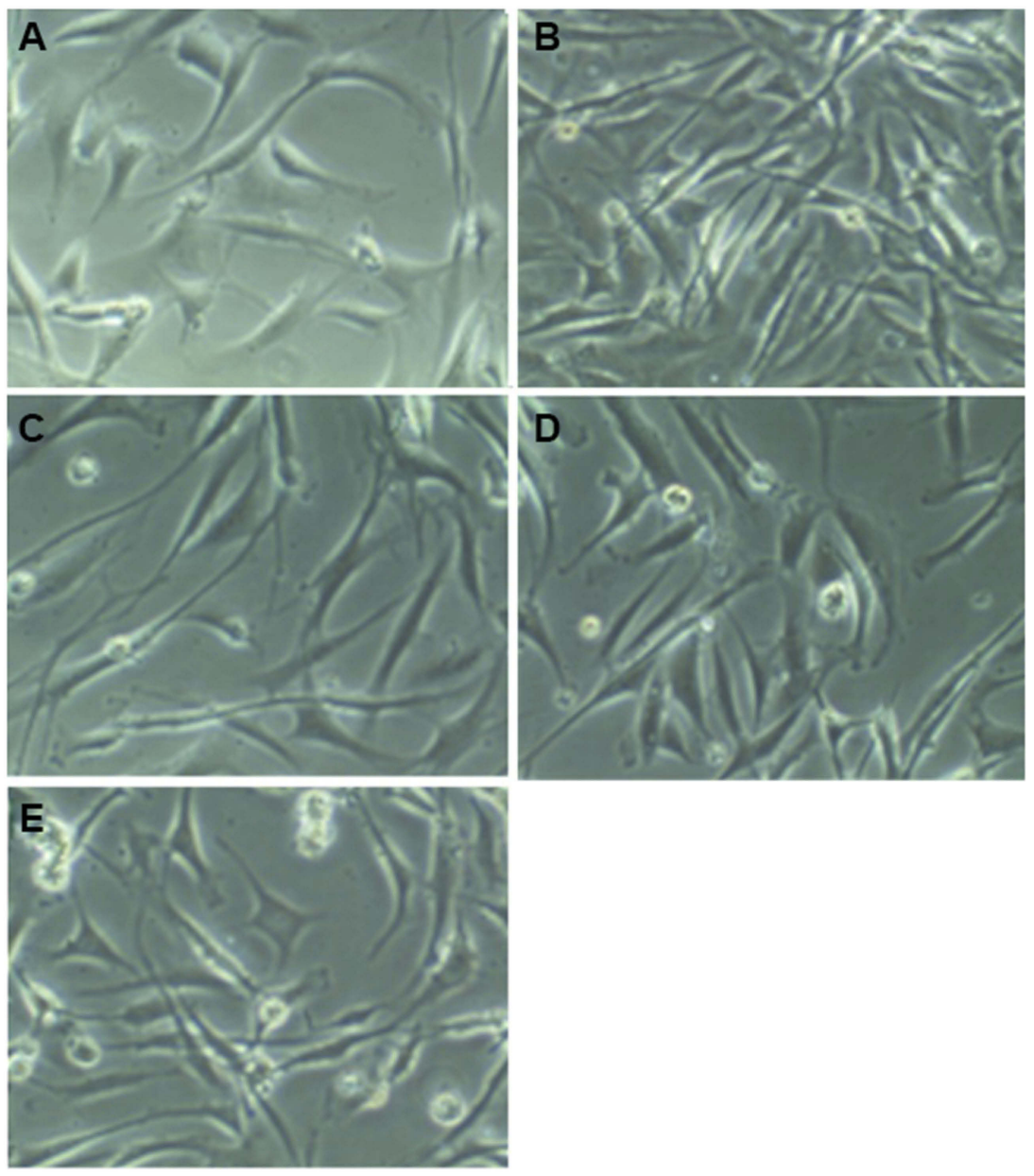

Figure 12 Morphological changes of hMSCs induced by different concentrations of $\mathrm{SiO}_{2}[0$ (A), 10 (B), 50 (C), 100 (D) and $200 \mu \mathrm{g} / \mathrm{mL}$ (E)].

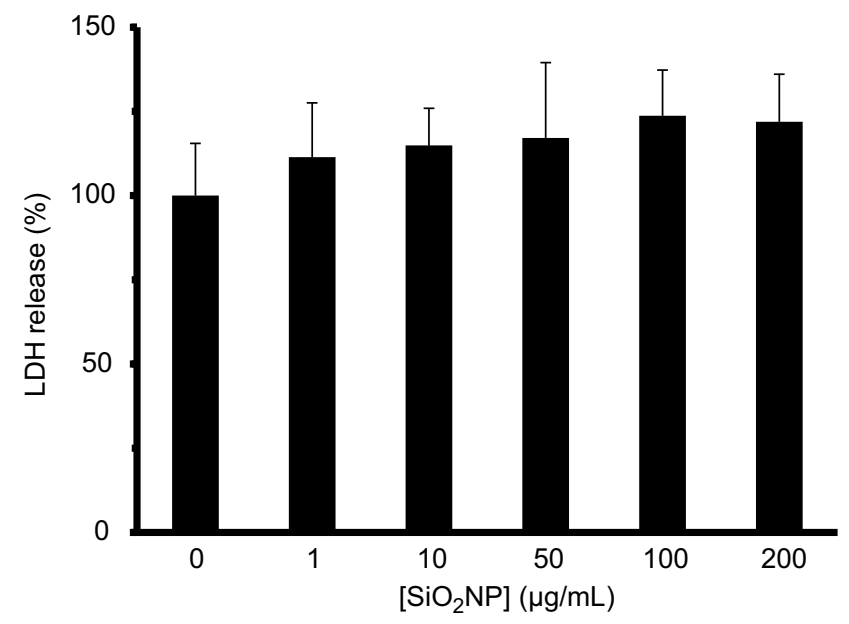

Figure $13 \mathrm{SiO}_{2} \mathrm{NPs}$ cause no increase in the level of LDH in cell culture medium. hMSCs cells were incubated with varying concentrations of $\mathrm{SiO}_{2} \mathrm{NPs}$ for $24 \mathrm{hrs}$ before examining the LDH activity of cell culture medium.

observed at high concentration $\left(200 \mu \mathrm{g} / \mathrm{mL},\left[{ }^{*} P<0.05\right]\right)$. Consequently, it is evident that all concentrations of $\mathrm{SiO}_{2}$
NPs did not cause activation of caspases, and the effect is most significant at high concentrations of $\mathrm{SiO}_{2} \mathrm{NPs}$.

\section{Flow cytometry analysis}

To further quantify cell apoptosis and necrosis, hMSCs were exposed to $\mathrm{SiO}_{2}$ NPs with a concentration of $200 \mu \mathrm{g} / \mathrm{mL}$ and then stained by employing Annexin V-FITC/PI doublestaining method. The results are depicted in Figure 16, where $\mathrm{A}$ and $\mathrm{B}$ correspond to the representative plots of flow cytometry analysis in hMSCs in the absence and presence of $\mathrm{SiO}_{2}$ NPs $(200 \mu \mathrm{g} / \mathrm{mL})$, respectively. It can be seen from Figure 16A that almost no apoptotic or necrotic cells were discovered in negative control cells. Nevertheless, in the $\mathrm{SiO}_{2}$ NPs-treated sample, a significant increase in the population of apoptotic cells could be detected (Figure 16B). After $24 \mathrm{hrs}$ of incubation with $200 \mu \mathrm{g} / \mathrm{mL}$ of $\mathrm{SiO}_{2} \mathrm{NPs}$, the percentage of hMSCs cells going through early-stage apoptosis was $8.45 \%(* * P<0.01)$, indicating apoptosis induction in the hMSCs cells. As expected, lower concentrations of 


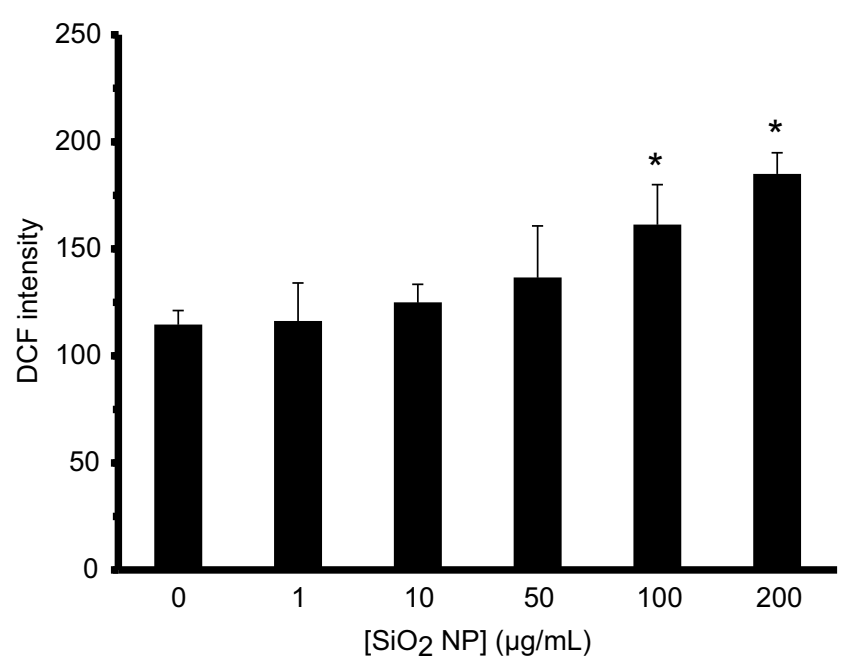

Figure $14 \mathrm{SiO}_{2}$ NPs at concentrations of 100 and $200 \mu \mathrm{g} / \mathrm{mL}$ increase the level of ROS in hMSCs. hMSCs cells were incubated with $\mathrm{SiO}_{2} \mathrm{NPs}$ for $24 \mathrm{hrs}$ before the ROS level was examined. $* P<0.05$ compared to control group.

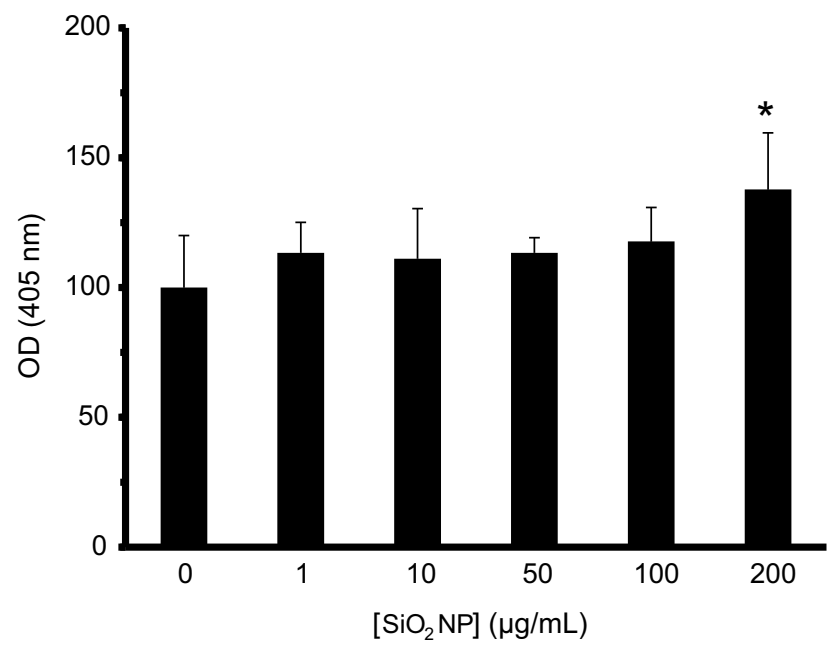

Figure $15 \mathrm{SiO}_{2}$ NPs at concentration of $200 \mu \mathrm{g} / \mathrm{mL}$ activate caspase- 3 in hMSCs. hMSCs cells were incubated with varying concentrations of $\mathrm{SiO}_{2} \mathrm{NPs}$ for 24 hrs before the caspase- 3 activity was assessed. $* P<0.05$ compared to control group.

$\mathrm{SiO}_{2} \mathrm{NPs}$ did not induce any significant changes in the number of viable or apoptotic cells relative to the control cells (data not shown). These data confirm again that $\mathrm{SiO}_{2}$ NPs induce apoptosis in hMSCs only at high concentration.

\section{Discussion}

Protein delivery ${ }^{37}$ or stem cell delivery ${ }^{2}$ can be used to treat several human disorders. For example, Scaletti et $\mathrm{al}^{38}$ revealed that NP-therapeutic protein supramolecular assemblies can be used to deliver therapeutic proteins into the cells. Cheng et $\mathrm{al}^{39}$ reported that metal-organic framework NPs can be applied as promising agents for protection and delivery of proteins. Zhang et $\mathrm{al}^{40}$ disclosed that NPs can be used as useful systems in stem cell delivery for treating some neurological disorders. Singhal et $\mathrm{al}^{41}$ reported that NP-mediated CAT delivery can mitigate the oxidative stress in human neurons. Song et $\mathrm{al}^{42}$ divulged that CAT-loaded nanoshells can be used as bionanoreactors and enzyme delivery carrier for increasing radiotherapy. Song et $\mathrm{al}^{43}$ showed that liposomes can be employed as excellent candidates for intracellular delivery of CAT. Li et $\mathrm{al}^{44}$ also suggested that some kind of nanosomes can be utilized as potential delivery and for increasing the bioactivity of CAT. In fact, as CAT delivery can be used to treat several diseases such as cancer therapy, ${ }^{45}$ ischemia/reperfusion, ${ }^{46}$ and vascular oxidative stress, ${ }^{47}$ the applications of NPs as efficient carriers can be used to deliver CAT to the target tissues. However, before application of NPs in delivery of therapeutic proteins or stem cells, the structure of proteins or cell viability should be evaluated in the presence of NPs. For these applications, the interaction of NPs with CAT should be investigated in order to explore the conformational changes and corresponding activity of CAT in the presence of NPs. In this paper, we demonstrated that $\mathrm{SiO}_{2}$ NPs did not significantly change the structure and activity of CAT. However, different studies have shown that multi-walled carbon nanotubes, ${ }^{48}$ $\mathrm{TiO}_{2} \mathrm{NPs},{ }^{49} \mathrm{~N}$-acetyl-L-cysteine-capped $\mathrm{CdTe}$ quantum dots, ${ }^{50}$ superparamagnetic iron oxide $\mathrm{NPs}^{51}$ and $\mathrm{TiO}_{2} / \mathrm{WO}_{3}$ /GO nanocomposites ${ }^{12}$ caused substantial structural and functional alterations of CAT.

hMSCs are being widely used for cell therapy and as targeted therapeutic agents. ${ }^{52}$ NPs can be used to develop a system including hMSCs-based cell engineering for tissue delivery. ${ }^{4}$ It has been also demonstrated that NPs can be used as agents to track the stem cells ${ }^{53,54}$ and promote their differentiation. ${ }^{55,56}$ On that account, it also seems necessary to explore the cytotoxicity of NPs against hMSCs to introduce some promising NPs which can be implemented with hMSCs as promising agents for therapeutic purposes. In the current study, we unveiled that $\mathrm{SiO}_{2}$ NPs up to $100 \mu \mathrm{g} / \mathrm{mL}$ do not induce a remarkable cytotoxicity against hMSCs. In spite of that, Mancuso et $\mathrm{al}^{57}$ and Kim et $\mathrm{al}^{58}$ depicted that $\mathrm{ZnO}$ NPs induce mortality, morphological changes, cell cycle arrest and apoptosis in hMSC. Yan et $\mathrm{al}^{59}$ also revealed that the surface charge of carbon quantum dots can play an important role in the NP-induced cytotoxicity against hMSCs.

Therefore, it may be concluded that $\mathrm{SiO}_{2}$ NPs do not induce remarkable changes on the CAT activity and cytotoxicity against hMSCs. Future studies may involve functionalization of $\mathrm{SiO}_{2}$ NPs with different moieties and integrating with CAT in order to increase the activity of 

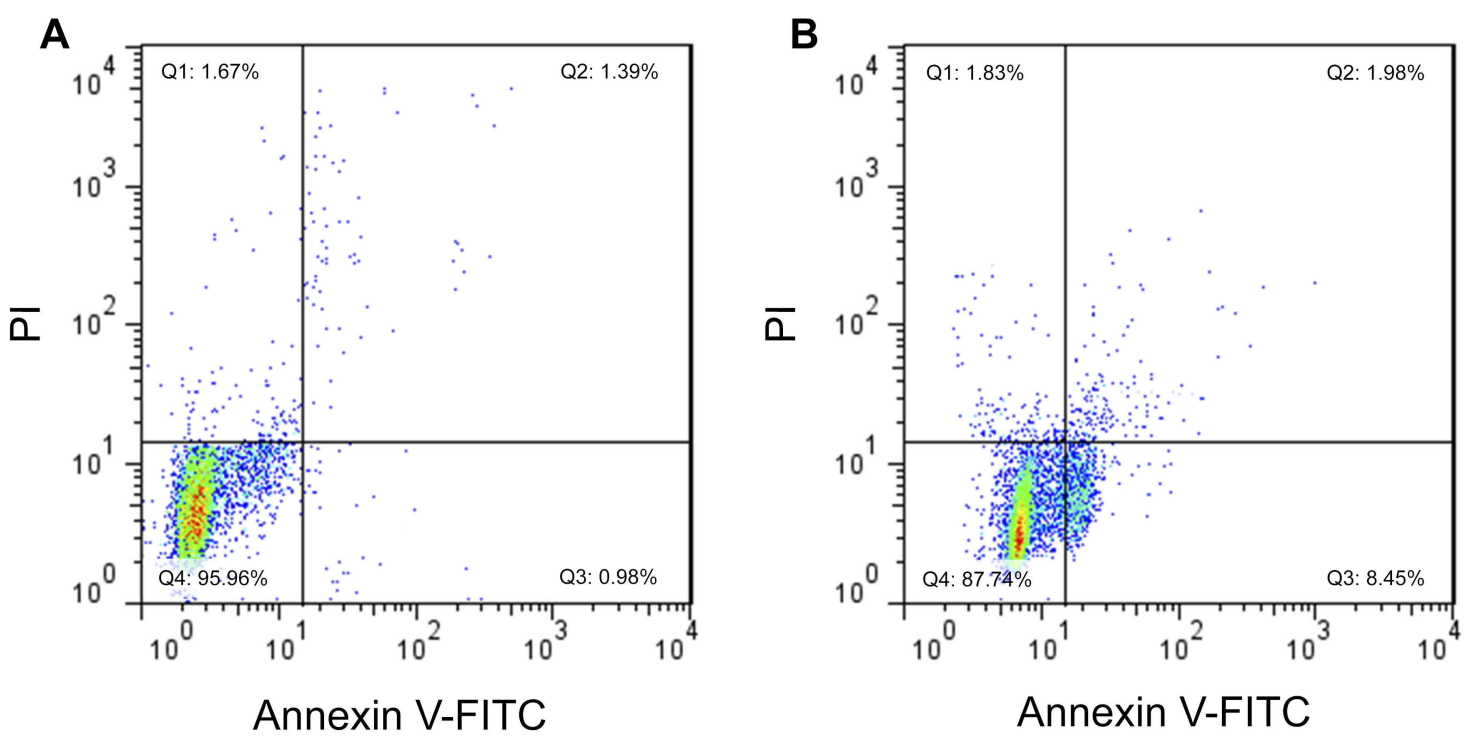

Figure 16 hMSCs cells were incubated with $200 \mu \mathrm{g} / \mathrm{mL}$ of $\mathrm{SiO}_{2} \mathrm{NPs}$ for $24 \mathrm{hrs}$, then co-stained with Annexin V-FITC/PI to quantify the apoptosis induction. (A) Control cells and (B) $\mathrm{SiO}_{2}$ NPs-treated cells.

CAT and promote the differentiation of hMSCs for stem cell therapy in high oxidative stress regions. Indeed, CAT delivery by NPs can mitigate the oxidative stress and promote the efficacy of hMSCs in cell therapy.

\section{Perspectives}

Both the toxicity assay and therapeutic potency of NPs are critically urgent for their utilization in biomedical applications. For both plans, it is vital to explore some basic queries regarding how the biomolecules or cells contact with NPs. One question is to know the factors influencing the cellular effects of NPs. In the present study, we have mainly developed our information about the biological impacts of $\mathrm{SiO}_{2} \mathrm{NPs}$; however, comprehensive investigations about the mechanisms of toxicity of bare NPs and NPs/protein complex should be performed. The complexity in the characteristic of NPs, the kind of cells and proteins and even physicochemical features affect the biological system-NP interactions. It would be important to explore how these parameters influence the protein structures and cellular vitality. This brand new information will receive an advantage in the perceptive development of monohybrids in the time ahead. The second query is the methodological challenge as well as the type of biological systems as models in exploring NP-protein and NP-cell interactions. These challenges should be addressed by selecting the best models and appropriate techniques for understanding the NP-protein/cell interactions.
Well-established methods are necessary to disclose how NPs like $\mathrm{SiO}_{2}$ NPs affect conformations and viability of proteins and cells, respectively. It is crucial to use the proper techniques to speculate prospective adverse effects to protein and cells. Some biophysical techniques as well as bioinformatical investigations are potential to unveil some information regarding the protein structure incubated with NPs. Cellular assays will also help scientists to clarify signal pathways to explore the outcome from cell-NP interactions. The third query is how to reveal the interfacial interaction details among NPs, proteins and cells. This research may help to provide comprehensive affirmation regarding the chemical mechanisms for protein and cellular impacts of $\mathrm{SiO}_{2} \mathrm{NPs}$. By addressing these matters, we can acquire more exhaustive data regarding the interaction of NP with proteins or cells and this data will be useful for the reasoned development of potential and biocompatible nanovehicles in the future.

\section{Conclusion}

CAT delivery by NPs may enhance the therapeutic efficacy of hMSCs by reducing the oxidative stress. However, NPs may induce some unwanted effects on the CAT structure and function and hMSCs viability. In this study, we explored the interaction of $\mathrm{SiO}_{2}$ NPs with CAT and hMSCs by different approaches. It was depicted that hydrophobic interactions are the main contributing forces in the spontaneous interaction of $\mathrm{SiO}_{2}$ NPs with CAT. Also, native structure and activity of CAT remain 
unchanged after interaction with $\mathrm{SiO}_{2}$ NPs. It was also demonstrated that $\mathrm{SiO}_{2}$ NPs triggered no remarkable cytotoxic effect against hMSCs till $100 \mu \mathrm{g} / \mathrm{mL}$. Finally, $\mathrm{SiO}_{2}$ $\mathrm{NP}$ in combination with CAT as a multipotent complex may enable efficient cell therapy in future.

\section{Disclosure}

The authors report no conflicts of interest in this work.

\section{References}

1. Yun Y, Cho YW, Park K. Nanoparticles for oral delivery: targeted nanoparticles with peptidic ligands for oral protein delivery. $A d v$ Drug Del Rev. 2013;65(6):822-832. doi:10.1016/j.addr.2012.10.007

2. Hao X, Xu B, Chen H, et al. Stem cell-mediated delivery of nanogels loaded with ultrasmall iron oxide nanoparticles for enhanced tumor MR imaging. Nanoscale. 2019;11(11):4904-4910.

3. Nayak PS, Borah SM, Gogoi H, et al. Lactoferrin adsorption onto silver nanoparticle interface: implications of corona on protein conformation, nanoparticle cytotoxicity and the formulation adjuvanticity. Chem Eng J. 2019;361:470-484. doi:10.1016/j.cej.2018.12.084

4. Huang X, Zhang F, Wang H, et al. Mesenchymal stem cell-based cell engineering with multifunctional mesoporous silica nanoparticles for tumor delivery. Biomaterials. 2013;34(7):1772-1780. doi:10.1016/j. biomaterials.2012.11.032

5. Popara J, Accomasso L, Vitale E, et al. Silica nanoparticles actively engage with mesenchymal stem cells in improving acute functional cardiac integration. Nanomedicine. 2018;13(10):1121-1138. doi:10.2217/nnm-2017-0309

6. Shao D, Li M, Wang Z, et al. Bioinspired diselenide-bridged mesoporous silica nanoparticles for dual-responsive protein delivery. $A d v$ Mater. 2018;30(29):1801198. doi:10.1002/adma.201801198

7. Croissant JG, Fatieiev Y, Almalik A, Khashab NM. Mesoporous silica and organosilica nanoparticles: physical chemistry, biosafety, delivery strategies, and biomedical applications. Adv Healthc Mater. 2018;7(4):1700831.

8. Falahati M, Attar F, Sharifi M, et al. A health concern regarding the protein corona, aggregation and disaggregation. Biochim Biophys Acta Gen Subj. 2019;1863:971-991. doi:10.1016/j.bbagen.2019.02.012

9. Yang Q, Liang J, Han H. Probing the interaction of magnetic iron oxide nanoparticles with bovine serum albumin by spectroscopic techniques. $J$ Phys Chem B. 2009;113(30):10454-10458. doi:10.1021/jp904004w

10. Ansari A, Sachar S, Garje SS. Synthesis of bare and surface modified $\mathrm{TiO} 2$ nanoparticles via a single source precursor and insights into their interactions with serum albumin. New J Chem. 2018;42 (16):13358-13366. doi:10.1039/C8NJ02253D

11. Pishkar L, Taheri S, Makarem S, et al. Studies on the interaction between nanodiamond and human hemoglobin by surface tension measurement and spectroscopy methods. J Biomol Struct Dyn. 2017;35(3):603-615. doi:10.1080/07391102.2016.1155172

12. Hao X, Zhang L, Zheng X, Zong W, Liu C. Molecular mechanism of composite nanoparticles $\mathrm{TiO} 2 / \mathrm{WO} / \mathrm{GO}$-induced activity changes of CAT and superoxide dismutase. Chem Biol Interact. 2018;292:30-36. doi:10.1016/j.cbi.2018.06.025

13. Bardhan M, Mandal G, Ganguly T. Steady state, time resolved, and circular dichroism spectroscopic studies to reveal the nature of interactions of zinc oxide nanoparticles with transport protein bovine serum albumin and to monitor the possible protein conformational changes. J Appl Phys. 2009;106(3):034701. doi:10.1063/1.3190483
14. Suliman YA, Ali D, Alarifi S, Harrath AH, Mansour L, Alwasel SH. Evaluation of cytotoxic, oxidative stress, proinflammatory and genotoxic effect of silver nanoparticles in human lung epithelial cells. Environ Toxicol. 2015;30(2):149-160. doi:10.1002/tox.21880

15. Kaviyarasu K, Geetha N, Kanimozhi K, et al. In vitro cytotoxicity effect and antibacterial performance of human lung epithelial cells A549 activity of Zinc oxide doped $\mathrm{TiO} 2$ nanocrystals: investigation of bio-medical application by chemical method. Mater Sci Eng C Mater Biol Appl. 2017;74:325-333. doi:10.1016/j.msec.2016.12.024

16. Ahamed M, Akhtar MJ, Khan MAM, Alrokayan SA, Alhadlaq HA. Oxidative stress mediated cytotoxicity and apoptosis response of bismuth oxide (Bi2O3) nanoparticles in human breast cancer (MCF-7) cells. Chemosphere. 2019;216:823-831. doi:10.1016/j. chemosphere.2018.10.214

17. Calero M, Gutierrez L, Salas G, et al. Efficient and safe internalization of magnetic iron oxide nanoparticles: two fundamental requirements for biomedical applications. Nanomedicine. 2014;10 (4):733-743. doi:10.1016/j.nano.2013.11.010

18. Ko TP, Safo MK, Musayev FN, et al. Structure of human erythrocyte CAT. Acta Crystallogr D Biol Crystallogr. 2000;56(Pt 2):241-245. doi:10.1107/s0907444999015930

19. Fisher SA, Cutler A, Doree C, et al. Mesenchymal stromal cells as treatment or prophylaxis for acute or chronic graft-versus-host disease in haematopoietic stem cell transplant (HSCT) recipients with a haematological condition. Cochrane Database Syst Rev. 2019;1: Cd009768. doi:10.1002/14651858.CD005619.pub3

20. Galleu A, Milojkovic D, Deplano S, et al. Mesenchymal stromal cells for acute graft-versus-host disease: response at 1 week predicts probability of survival. Br J Haematol. 2019;185(1):89-92. doi:10.1111/bjh.15749

21. Xu C, Wang S, Liu L, Yu S, Wu X, Dai H. Manipulating mesenchymal stem cells differentiation under sinusoidal electromagnetic fields using intracellular superparamagnetic nanoparticles. J Biomed Nanotechnol. 2019;15(2):301-310. doi:10.1166/jbn.2019.2683

22. Han J, Kim B, Shin JY, et al. Iron oxide nanoparticle-mediated development of cellular gap junction crosstalk to improve mesenchymal stem cells' therapeutic efficacy for myocardial infarction. ACS Nano. 2015;9(3):2805-2819. doi:10.1021/nn506732n

23. Parkash J, Sharma A, Jairath A. Embryonic stem cell as a cellular model for testing the toxicity of engineered nanoparticles. In: Kumar V, Dasgupta N, Ranjan S, editors. Nanotoxicology. CRC Press; 2018:613-634.

24. Munde MS, Gao DZ, Shluger AL. Diffusion and aggregation of oxygen vacancies in amorphous silica. $J$ Phys Condens Matter. 2017;29(24):245701.

25. Sabziparvar N, Saeedi Y, Nouri M, et al. Investigating the interaction of silicon dioxide nanoparticles with human hemoglobin and lymphocyte cells by biophysical, computational, and cellular studies. $J$ Phys Chem B. 2018;122(15):4278-4288. doi:10.1021/acs.jpcb.8b00193

26. Frisch M, Trucks G, Schlegel H, et al. Gaussian 98, Revision a. 7. Pittsburgh (PA): Gaussian Inc.; 1998:12.

27. Ritchie DW, Venkatraman V. Ultra-fast FFT protein docking on graphics processors. Bioinformatics. 2010;26(19):2398-2405. doi:10.1093/bioinformatics/btq444

28. Rappé AK, Casewit CJ, Colwell K, Goddard III WA, Skiff W. UFF, a full periodic table force field for molecular mechanics and molecular dynamics simulations. $J$ Am Chem Soc. 1992;114 (25):10024-10035. doi:10.1021/ja00051a040

29. Pourgholaminejad A, Aghdami N, Baharvand H, Moazzeni SM. The effect of pro-inflammatory cytokines on immunophenotype, differentiation capacity and immunomodulatory functions of human mesenchymal stem cells. Cytokine. 2016;85:51-60. doi:10.1016/j.cyto.2016.06.003

30. Babadaei MMN, Moghaddam MF, Solhvand S, et al. Biophysical, bioinformatical, cellular, and molecular investigations on the effects of graphene oxide nanosheets on the hemoglobin structure and lymphocyte cell cytotoxicity. Int $J$ Nanomedicine. 2018;13:6871. doi:10.2147/IJN.S177627 
31. Azimipour S, Ghaedi S, Mehrabi Z, et al. Heme degradation and iron release of hemoglobin and oxidative stress of lymphocyte cells in the presence of silica nanoparticles. Int J Biol Macromol. 2018;118(Pt A):800-807. doi:10.1016/j.ijbiomac.2018.06.128

32. Abdelhameed AS, Bakheit AH, AlRabiah HK, Hassan ESG, Almutairi FM. Molecular interactions of AL3818 (anlotinib) to human serum albumin as revealed by spectroscopic and molecular docking studies. J Mol Liq. 2019;273:259-265. doi:10.1016/j.molliq.2018.10.025

33. Vanekova Z, Hubcik L, Toca-Herrera JL, et al. Study of interactions between amlodipine and quercetin on human serum albumin: spectroscopic and modeling approaches. Molecules. 2019;24:3. doi:10.3390/ molecules 24030487

34. Ali MS, Al-Lohedan HA. Experimental and computational investigation on the molecular interactions of safranal with bovine serum albumin: binding and anti-amyloidogenic efficacy of ligand. $\mathrm{J} \mathrm{Mol}$ Liq. 2019;278:385-393. doi:10.1016/j.molliq.2019.01.034

35. Agrawal R, Thakur Y, Tripathi M, Siddiqi MK, Khan RH, Pande R. Elucidating the binding propensity of naphthyl hydroxamic acid to human serum albumin (HSA): multi-spectroscopic and molecular modeling approach. J Mol Struct. 2019;1184:1-11. doi:10.1016/j. molstruc.2019.01.067

36. Moosavi MA, Sharifi M, Ghafary SM, et al. Photodynamic N-TiO 2 nanoparticle treatment induces controlled ROS-mediated autophagy and terminal differentiation of leukemia cells. Sci Rep. 2016;6:34413. doi:10.1038/srep34413

37. Yu M, Wu J, Shi J, Farokhzad OC. Nanotechnology for protein delivery: overview and perspectives. $J$ Control Release. 2016;240:24-37. doi:10.1016/j.jconrel.2015.10.012

38. Scaletti F, Hardie J, Lee Y-W, Luther DC, Ray M, Rotello VM. Protein delivery into cells using inorganic nanoparticle-protein supramolecular assemblies. Chem Soc Rev. 2018;47(10):3421-3432. doi: $10.1039 / \mathrm{c} 8 \mathrm{cs} 00008 \mathrm{e}$

39. Cheng G, Li W, Ha L, et al. Self-assembly of extracellular vesicle-like metal-organic framework nanoparticles for protection and intracellular delivery of biofunctional proteins. J Am Chem Soc. 2018;140(23):7282-7291. doi:10.1021/jacs.8b03584

40. Zhang G, Khan AA, Wu H, Chen L, Gu Y, Gu N. The application of nanomaterials in stem cell therapy for some neurological diseases. Curr Drug Targets. 2018;19(3):279-298. doi:10.2174/1389450118 666170328115801

41. Singhal A, Morris VB, Labhasetwar V, Ghorpade A. Nanoparticlemediated CAT delivery protects human neurons from oxidative stress. Cell Death Dis. 2013;4(11):e903-e903. doi:10.1038/cddis.2013.362

42. Song G, Chen Y, Liang C, et al. CAT-loaded TaOx nanoshells as bio-nanoreactors combining high-Z element and enzyme delivery for enhancing radiotherapy. Adv Mater. 2016;28(33):7143-7148. doi:10.1002/adma.201602111

43. Song X, Xu J, Liang C, Chao Y, Jin Q, Wang C, Chen M, Liu Z. Selfsupplied tumor oxygenation through separated liposomal delivery of $\mathrm{H} 2 \mathrm{O} 2$ and catalase for enhanced radio-immunotherapy of cancer. Nano letters. 2018;18(10):6360-6368.

44. Li Y, Zhou Y, Han W, et al. Novel lipidic and bienzymatic nanosomes for efficient delivery and enhanced bioactivity of CAT. Int J Pharm. 2017;532(1):157-165. doi:10.1016/j.ijpharm.2017.09.006

International Journal of Nanomedicine

\section{Publish your work in this journal}

The International Journal of Nanomedicine is an international, peerreviewed journal focusing on the application of nanotechnology in diagnostics, therapeutics, and drug delivery systems throughout the biomedical field. This journal is indexed on PubMed Central, MedLine, CAS, SciSearch ${ }^{\mathbb{B}}$, Current Contents ${ }^{\mathbb{B}} /$ Clinical Medicine, $^{2}$
45. Zhang R, Song X, Liang C, et al. CAT-loaded cisplatin-prodrugconstructed liposomes to overcome tumor hypoxia for enhanced chemo-radiotherapy of cancer. Biomaterials. 2017;138:13-21. doi:10.1016/j.biomaterials.2017.05.025

46. Akateh C, Beal EW, Kim JL, et al. Intrahepatic delivery of pegylated CAT is protective in a rat ischemia/reperfusion injury model. $J$ Surg Res. 2019;238:152-163. doi:10.1016/j.jss.2019.01.028

47. Sari E, Tunc-Sarisozen Y, Mutlu H, Shahbazi R, Ucar G, Ulubayram K. ICAM-1 targeted CAT encapsulated PLGA-b-PEG nanoparticles against vascular oxidative stress. J Microencapsul. 2015;32(7):687-698. doi:10.3109/02652048.2015.1073384

48. Fan Y, Li Y, Cai H, et al. Fluorescence spectrometry of the interaction of multi-walled carbon nanotubes with CAT. J Appl Spectrosc. 2014;81(5):795-800. doi:10.1007/s10812-014-0016-5

49. Zhang HM, Cao J, Tang BP, Wang YQ. Effect of TiO(2) nanoparticles on the structure and activity of CAT. Chem Biol Interact. 2014;219:168-174. doi:10.1016/j.cbi.2014.06.005

50. Sun H, Yang B, Cui E, Liu R. Spectroscopic investigations on the effect of N-acetyl-L-cysteine-capped CdTe quantum dots on CAT. Spectrochim Acta A Mol Biomol Spectrosc. 2014;132:692-699. doi:10.1016/j.saa.2014.04.157

51. Yu Z, Liu H, Hu X, Song W, Liu R. Investigation on the toxic interaction of superparamagnetic iron oxide nanoparticles with CAT. J Lumin. 2015;159:312-316. doi:10.1016/j.jlumin.2014.10.049

52. Wei X, Yang X, Han ZP, Qu FF, Shao L, Shi YF. Mesenchymal stem cells: a new trend for cell therapy. Acta Pharmacol Sin. 2013;34 (6):747-754. doi:10.1038/aps.2013.50

53. Huang D-M, Hung Y, Ko B-S, et al. Highly efficient cellular labeling of mesoporous nanoparticles in human mesenchymal stem cells: implication for stem cell tracking. FASEB J. 2005;19 (14):2014-2016. doi:10.1096/fj.05-4288fje

54. Gu L, Li X, Jiang J, et al. Stem cell tracking using effective self-assembled peptide-modified superparamagnetic nanoparticles. Nanoscale. 2018;10(34):15967-15979. doi:10.1039/c7nr07618e

55. Yi C, Liu D, Fong CC, Zhang J, Yang M. Gold nanoparticles promote osteogenic differentiation of mesenchymal stem cells through p38 MAPK pathway. ACS Nano. 2010;4(11):6439-6448. doi:10.1021/nn101373r

56. Zhang J, Chen Y, Gao M, et al. Silver nanoparticles compromise female embryonic stem cell differentiation through disturbing X chromosome inactivation. ACS Nano. 2019;13(2):2050-2061. doi:10.1021/acsnano.8b08604

57. Mancuso L, Manis C, Murgia A, Isola M, Salis A, Piras F. Effect of $\mathrm{ZnO}$ nanoparticles on human bone marrow mesenchymal stem cells: viability, morphology, particles uptake, cell cycle and metabolites. Biosciences Biotechnol Res Asia. 2018;15(4):751-765. doi:10.13005/ bbra/2684

58. Kim D-Y, Kim J-H, Lee J-C, et al. Zinc oxide nanoparticles exhibit both cyclooxygenase-and lipoxygenase-mediated apoptosis in human bone marrow-derived mesenchymal stem cells. Toxicol Res. 2019;35 (1):83. doi:10.5487/TR.2019.35.1.083

59. Yan J, Hou S, Yu Y, et al. The effect of surface charge on the cytotoxicity and uptake of carbon quantum dots in human umbilical cord derived mesenchymal stem cells. Colloids Surf B Biointerfaces. 2018;171:241-249. doi:10.1016/j.colsurfb.2018.07.034

Journal Citation Reports/Science Edition, EMBase, Scopus and the Elsevier Bibliographic databases. The manuscript management system is completely online and includes a very quick and fair peer-review system, which is all easy to use. Visit http://www.dovepress.com/ testimonials.php to read real quotes from published authors. 